DOI: 10.36695/2219-5521.2.2020.01

УДК 340.12 (477)(091)

\title{
T.I. БОНДАРУК
}

Тетяна Іванівна Бондарук, кандидат юридичних наук, старший науковий співробітник, старший науковий співробітник Інституту держави і права імені В.М. Корецького НАН України*

ORCID: 0000-0003-0566-9857

\section{ВИДАТНИЙ УКРАЇНСЬКИЙ ПРАВОЗНАВЕЦЬ МИКОЛА ОЛЕКСІЙОВИЧ МАКСИМЕЙКО (до 150-річчя від дня народження)}

Українське правознавство має давню історію, кожний етап якої важливий для сьогодення. Друга половина XIX ст. - перша половина XX ст. $є$ золотим часом у становленні й утвердженні української гуманітаристики та історико-правової науки, зокрема. Професор М.О. Максимейко - один із тих учених, які творили цей культурно-правовий феномен. Життя і наукова творчість істориків права, а М.О. Максимейко в офіційних документах завжди позиціонував себе саме так, - невід'ємна складова історії правознавства. Його творчий доробок все ще потребує дослідження, аналізу і на цій основі - актуалізації та переосмислення.

Постать М.О. Максимейка, його наукова діяльність не були виключені з наукового обігу тотально. Статті про науковця були вміщені у багатьох довідкових виданнях ${ }^{1}$, до його досліджень зверталися і звертаються дослідники Руської Правди, литовсько-руського (західноруського) права, державних і правових інституцій Великого князівства Литовського і Речі Посполитої Ст. Кутшеба, В.І. Пічета, М.М. Тихомиров, О.О. Зімін, М.Б. Свердлов, Р.Л. Хачатуров, С.В. Юшков та багато інших вчених. Справжнє ж повернення науковця у науку відбулося після появи розвідок О.Ф. Скакун «М.О. Максимейко - історик» (1970 р.) та «Максимейко как историк права» (1971р.) та ін. На сьогодні полиця досліджень виглядає доволі солідно. Завдяки зусиллям С.I. Михальченка, О.М. Богдашиної, І.Б. Усенка, Т.І. Бондарук, М.А. Дамірлі, О.В.Кресіна, С.В. Кудіна, T.C. Федько та ін. Микола Олексійович Максимейко як освітній діяч, науковець, член-кореспондент ВУАН посів своє місце у пантеоні видатних українських правознавців. 2008 р. С.В. Остапенко здійснила дисертаційне дослідження, в якому на основі архівних матеріалів, серед яких особові і службові справи М.О. Максимейка у Центральному державному архіві вищих органів влади і управління України (ф. 8. оп. 1. спр. 257, 263; ф. 166, оп. 6. спр. 4214, 4580; оп. 12, спр. 4618) та Науковому архіві Президії НАН України, (ф. 251) представила цілісну картину науково-педагогічної та громадської діяльності М.О. Максимейка². Водночас багатогранність особистості професора Максимейка та його творчого доробку викликає дослідницький інтерес і спонукає до подальших студій.

Виходячи 3 цих міркувань, мета даної статті полягає в тому, щоб окреслити життєвий та науково-педагогічний шлях відомого історика права та висвітлити ключові питання його творчого спадку у контексті розвитку історико-правової науки.

Народився майбутній правознавець 5(16) червня 1870 р. у с. Волошинівка Роменського повіту Полтавської губернії (нині - Роменський район Сумської області у родині вихідців із селянства. «В сільській школі, Прилуцькій гімназії (чотири класи), Колегії Павла Галагана, Київському університеті (юридичний факультет)» - відповів на питання «У яких навчальних закладах навчався?» в особовій справі тоді вже викладач Харківського геодезичного та землевпорядного інституту Максимейко (1925р.).

Головним же освітнім закладом для нього, як і для багатьох визначних науковців, юристів, медиків, літераторів зламу століть, стала Колегія Павла Галагана (1869-1920рр.), яка «не тільки готувала молодь до навчання в університеті, а й сприяла виробленню у колегіатів готовності присвятити своє життя суспільно корисній діяльності ... була одним з небагатьох навчальних закладів, навчально-виховна система якого частково базувалася на українській національній ідеї», - згадував Максимейко («Воспоминания, прочитанные на

(C) T.I. Бондарук, 2020

* Tetyana Bondaruk, Ph.D. in Law, Senior Researcher, Senior Researcher of V.M. Koretsky Institute of State and Law of the NAS of Ukraine 
заседании бывших воспитанников коллегии П. Галагана». Ежегодник коллегии П. Галагана. 1897 р.). Стипендіат колегії, зарахований «за конкурсовим іспитом», він, безсумнівно, примножив славу цього визначного навчального закладу.

Після закінчення з відзнакою Київського університету св. Володимира (1892р.) (за твір «Источники уголовных законов Литовского Статута» (1894р.) талановитий випускник був відзначений золотою медаллю) М.О. Максимейко упродовж 1893-1895 рр. - професорський стипендіат кафедри державного права. Його науковими керівниками стали М.Ф. Владимирський-Буданов і О.В. Романович-Славатинський. У «Ходатайстве факультета об оставлении Н. Максимейко стипендиатом и предоставлении ему стипендии» серед іншого відзначалися знання мов французької і німецької, відмінні оцінки з обраних предметів, талановитість і любов до справи; бездоганна моральністю; здатність правильно і вільно висловлювати свої думки³.

1896 р. молодий дослідник склав іспити на ступінь магістра державного права і після двох «пробних» лекцій М.О. Максимейку було надано звання приват-доцента Київського університету.

Все це обіцяло блискучу наукову кар’єру. І надії цілком виправдалися, про що свідчить більш як 45-річна дослідницька та викладацька діяльність М.О. Максимейка, яка офіційно розпочалася 1 серпня 1897 р., коли його було призначено приват-доцентом, а 7 вересня 1902 р. після успішного захисту дисертації і здобуття ступінь магістра державного права, - виконуючим обов'язки екстраординарного професора кафедри історії російського права юридичного факультету Харківського університету.

Початок Першої світової війни М.О. Максимейко зустрів у Берліні та Парижі, де влітку 1914 р. перебував у науковому відрядженні, а вже 22 лютого 1915 р. він успішно захистив докторську дисертацію «Опыт критического исследования Русской Правды», здобув ступінь доктора наук та став ординарним професором кафедри історії російського права юридичного факультету Харківського університету․

З 1915 р. разом із відомими педагогами В.П. Бузескулом, Д.І. Багалієм, М.Ф. Сумцовим та іншими професорами Харківського університету він, підтримуючи емансипаційну хвилю, викладає історію права на жіночих курсах ${ }^{5}$, створених 1907 р. за клопотанням Товариства взаємодопомоги трудящих жінок як школа університетського типу (до 1919 р.).

Після 1917 р. науковець продовжує епізодичну викладацьку діяльність у університеті, зокрема викладає курс історії українського права на відкритій 30 травня 1918 р. на юридичному факультеті кафедрі південноруського (тобто українського) права. Після припинення у листопаді 1919 р. занять у Харківському університеті М.О. Максимейко виступає з доповідями на засіданнях юридичного товариства, як член Харківського товариства поширення у народі грамотності читає лекції в секції суспільствознавства Мандрівного університету. 3 приходом денікінців у 1919 р., як і більшість викладачів Харківського університету, М.О. Максимейко входить до складу Академічного Союзу на допомогу Добровольчій армії та читає лекції для населення.

У 1920 р. у зв’язку з реорганізацією Харківського університету М.О. Максимейка призначено спочатку професором по кафедрі історії держави і права для читання курсу з «Історії права», а згодом - деканом юридичного факультету правового відділення Харківського інституту народного господарства.

Паралельно з березня 1920 р. він працював вченим консультантом кодифікаційного відділу Народного комісаріату юстиції УСРР. Разом із О.І. Хмельницьким, В.І. Сливицьким, О.Л. Малицьким та іншими юристами займався практичними та теоретичними питаннями кодифікації і державотворення. Зокрема, брав участь у роботі комісії з видання інструкцій та порядку провадження цивільних і кримінальних процесів; комісії з обрання додаткових постанов Тимчасового положення про Народні суди та положення про органи юстиції; комісії з опрацювання інструкцій для народних слідчих тощо.

Протягом 1920-1921 pр. М.О. Максимейко задля покращення стану здоров’я був вимушений залишити як освітню, так і громадсько-політичну роботу і тимчасово переїхав на малу батьківщину до Полтавщини. Тут науковець, незважаючи на хворобу, продовжував викладацьку діяльність у професійних соціально-економічній, агрономічній та педагогічній школах Полтавщини. Крім того, виступав з публічними лекціями 3 права, політичної економії та загальної історії.

1924 р. М.О. Максимейко повернувся до Харкова, де упродовж трьох місяців працював архіваріусом у Харківському історичному архіві. С.В. Остапенко припускає, що допомогу в працевлаштуванні науковцю надав Д.І. Багалій, який на той час був головою Центрального архівного управління.

Цього ж року було задоволено клопотання ученого «у зв’язку з тяжким матеріальним станом та відсутністю роботи» про викладання у Харківському геодезичному та землевпорядному інституті - спочатку позаштатним, а від 15 грудня 1927 р. - штатним професором історії аграрних відносин I групи.

Значною подією для ученого стало обрання, за дієвої підтримки академіка ВУАН М.П. Василенка, членом-кореспондентом ВУАН (1925 р.). 31926 р. М.О. Максимейко - член Комісії для виучування історії західноруського та українського права при соціально-економічному відділі ВУАН, головою якої був М.П. Василенко.

У жовтні 1926 р. М.О. Максимейко став співробітником та головою секції історії українського права, відкритої при науково-дослідній кафедрі історії української культури Харківського інституті народної освітиб.

У 1929 р. кандидатура професора Максимейка була висунута від Харківського геодезичного та землевпорядного інституту на вибори академіків до ВУАН. В характеристиці, підготовленій за дорученням колективу співробітників вишу професором О.М. Шебаліним, М.О. Максимейко характеризується як один із видатних дослідників історії українського права, його величезна ерудиція, велика, що до сих пір не скорочується ... науково-дослідна робота з історії України, його авторитет в цій галузі як такі, що дають повні підстави для обрання його академіком ВУАН». Однак академіком йому стати не судилося. Його кандидатура підтримана не була - за офіційною версією «так як не було катедр з відповідного фаху»7. Водночас, як зауважує С.В. Остапенко, свій вплив тут мала критика діяльності Харківської науково-дослідної кафедри історії 
української культури, у складі якої працював учений, на першій Всесоюзній конференції істориків-марксистів у Москві (грудень, 1928 р.).

У 30-х рр. ХХ ст. М.О. Максимейко продовжував педагогічну та наукову діяльність: до 1933 р. викладав у Харківському геодезичному та землевпорядному інституті та до 1934 р. очолював секцію історії українського права при Науково-дослідному інституті історії української культури ім. Д.І. Багалія аж до їх реорганізації, після чого науковець офіційно вийшов на пенсію, але не припинив дослідницької і викладацької діяльності.

Так, упродовж 1934-1936 рр. М.О. Максимейко працював у Науково-дослідному інституті імені Тараса Шевченка (Харків-Київ), готуючи коментарі і матеріали до «Повного зібрання творів» Т.Г. Шевченка, яке, на жаль лишилося незавершеним - у 1935-1937 рр. побачили світ перші два томи, у які матеріали науковця не увійшли.

У 1940-1941 рр. він викладав курс джерелознавства на історичному факультеті Харківського державного університету. І лише два тижні з 1 квітня до дня смерті 14 квітня 1941 р. «великий науковець М.О. Максимейко», як встигнув охарактеризувати його тодішній директор Інституту історії України Академії наук УРСР С.М. Бєлоусов, працював старшим науковим співробітником цього інституту. Помер Микола Олексійович Максимейко на сімдесят першому році життя у Харкові.

Як бачимо, науково-викладацька, громадська, просвітницька діяльність М.О. Максимейка була багатогранною. Можна сказати, він, інколи вимушено, проявляв різні грані свого таланту. Маючи постійний предмет наукового зацікавлення - історію права, учений займався різними проблемами юридичної науки і практики, демонструючи високий фах та аналітичне мислення, тонке розуміння права, історії, літератури.

Активною була організаторська та громадська діяльність ученого. Серед іншого, слід згадати його роботу з підготовки археологічних з'їдів, які були важливими подіями у тогочасному культурному і науковому житті. Багато зусиль докладав він як декан юридичного факультету Харківського інституту народного господарства для підтримання його життєдіяльності у складні часи. Брав він і активну участь у багатьох наукових товариствах та спілках, зокрема таких поважних, як Харківське юридичне товариство (з 1900 р.), Харківське історико-філологічне товариство (з 1897 р.).

Очевидно, не міг він залишитись осторонь політичних процесів початку ХХ ст. Симпатії М.О. Максимейка, як і значної частини інтелектуальної еліти, серед представників якої зокрема І.В. Лучицький, В.П. Науменко, Л.М. Яснопольський, Д.І. Багалій, М.П. Василенко, О.О. Малиновський, привернуло «намагання вирішити невідкладні і тому практично здійсненні потреби сучасної політичної і соціальної культури» конституційно-демократичної партії. М.О. Максимейко не був пов'язаний з нею членськими зобов'язаннями, але підтримував програму партії («оскільки вона не насичена класовими інтересами, а служить для прогресу країни»). Зокрема, він поділяв положення про загальне, рівне, пряме та таємне голосування на виборах, про аграрну реформу і земельну власність тощо та не вважав конституційну монархію «відступом від демократичних ідеалів ... адже, як писав учений у статті «Суть конституционно-демократической программы» (Мир. 1905. № 1), хоча ідея демократії та принцип народного самодержавства найбільш чітко виражається у республіці, на практиці серед реальних умов та законів культури переважає монархія».

Реформаторські настрої, спричинені подіями 1905-1907 рр., доволі швидко змінилися певною апатією M.O. Максимейка не задовольняв хід суспільного розвитку. Фактично лише прихід до влади П. Скоропадського і створення у Харківському, як і у Київському та Одеському університетах, кафедри української мови, літератури, історії та історії права (західноруського (українського) права), дістали позитивний відгук ученого. Згодом він активно включився у реалізацію політики українізації (коренізації), започаткованої у 20 -х рр. радянською владою.

Власне «мовчання» ученого у складний період суспільних зрушень, а подекуди і гостра самокритика ${ }^{8}$, дали йому можливість уникнути повсякчасних для «старої» інтелігенції утисків і покарань (згадаємо, зокрема, долі М.П. Василенка, О.О. Малиновського та ін.) та вижити в ті буремні часи. Можна сказати, що для М.О. Максимейка, як і для всього покоління гуманітаріїв зламу XIX-XX ст., типовою була ситуація «подвійної лояльності» - зацікавлення українськими питаннями реалізовувалося на посадах спочатку в імператорських університетах Києва і Харкова, а потім у радянських установах, що, очевидно, мало свій вплив на життя і дослідження.

Коло дослідницьких інтересів професора Максимейка доволі широке, що, однак, дає можливість виокремити певні доволі умовні періоди його наукової творчості.

Так, перший «київський період» ученого - це період дослідження литовсько-руського або західноруського права. За випускну працю9 він отримав свою першу відзнаку - золоту медаль і схвальний, навіть порівняно зі своїм товаришем і колегою О.О. Малиновським, відгук рецензента, який відзначав «знання мови польської і латинської» та порівняльний метод автора, який «не обмежується простим співставленням, а постійно намагається вникнути в дух рецепції» 10 . Зацікавлення державністю Великого князівства Литовського і Речі Посполитої (XIV-XVI ст.) науковець зберіг на все життя. Безперечним здобутком тут $є$ його магістерська дисертація «Сеймы Литовско-Русского государства до Люблинской унии 1569 г.» (1902 р.), яку він не без складнощів, з огляду на подібну працю М. К. Любавського «Литовско-русский сейм. Опыт по истории учреждения в связи с внутренним строем и внешней жизнью государства» (1900 р.), успішно захистив та яка до сьогодні лишається в активному науковому обігу. Принагідно слід зазначити, що полеміка між цими науковцями заслуговує окремого аналізу та визнати, що М.О. Максимейко у ії перебігу продемонстрував найкращі якості диспутанта - «одночасно і якості полеміста і неупередженого судді»11. Та основне, досліджуючи праводержавність Великого князівства Литовського, він аргументував власну позицію щодо окремішності права західноруського, а власне українського, чітко розрізняючи «три правні системи»: 
«1) право Північно-Східної Росії, яке знайшло своє вираження в московських Судебниках, в Уложенні 1649 р.; 2) право Литовської Русі, кращим втіленням якого є Литовський Статут, і 3) право Північно-Західного краю, кодифіковане в Судних грамотах Новгорода і Пскова» ${ }^{12}$.

«Коли я собі пригадую, - пише рецензент М.С. Грушевський, - як я з автором сих останніх виводів, сидючи за двома сусідніми столиками в київськім архіві кільканадцять літ тому, балакав на тему існування ріжниць в правних відносинах України і північних, великоруських земель в староруських часах, і добродій Максимейко висловляв сумніви на мої виводи про існування таких ріжниць, то я, розуміється, не без приємності перечитую вищенаведену диференціацію його».

Водночас висловив він і власне переконання, що «землі Київська, Чернігівська, Переяславська не мали ніякого безпосереднього впливу на еволюцію суспільних і правних норм Великого князівства Литовського» і отже, «зв'язі «Руської правди» й права Великого князівства Литовського немає»13. Це твердження спричинило до фактичного виключення зі сфери українського правознавства цього права. Разом із тим уявляється, що ключова розбіжність у поглядах дослідників пояснюється, по-перше, предметом дослідження, - юридичний масив, досліджуваний професором Максимейком як такий не був предметом зацікавлення професора Грушевського. Різним був і їх масштаб. Так, М.С. Грушевський складав «схему української історії», як всяка схема вона не мала враховувати «непрямі» впливи, запозичення та рецепції у праві і правових пам'ятках цих періодів, безперечно наявні і важливі, що переконливо доводить сучасна українська літуаністика. Можна стверджувати, що висновки М.О. Максимейка чи ненайкраще сприяли концептуалізації державно-правового розвитку руських земель у період їх входження до складу Великого князівства Литовського у працях Київської історико-юридичної школи ${ }^{14}$.

Власне, бачення М.О. Максимейком історичного розвитку українського права (українське право - право козацької України, що через Литовський Статут зв'язується з Руською Правдою та є старшим і за змістом багатшим за право Московське15) відповідало, покладеному в основу роботи Комісії для виучування західноруського і українського права ВУАН загальному уявленню Комісії про розгляд українського права, особливо в частині зв'язку між староруським і західноруським правом, додатково аргументуючи його ${ }^{16}$, плідна діяльність якої забезпечила сучасні історико-правові студії надійним фундаментом. Українське право, на його думку, впливало на загальнодержавне (литовсько-руське) і було одним із джерел Литовського Статуту, а тому цей кодекс можна вважати почасти кодексом українського права.

«Харківський період» - це період усталення методології досліджень, зокрема декларація прихильності до порівняльно-правового методу, узагальнення ходу історико-правового розвитку і створення циклу праць, присвячених «Руській Правді».

Так, інаугураційна лекція М.О. Максимейка на юридичному факультеті Харківського університету «Сравнительное изучение истории права» (1898р.) стала бестселером та висунула його разом з М.М. Ковалевським, Ф.В. Тарановським у перший ряд правознавців-компаративістів. Ця програмна праця, як і застосування порівняльно-правового інструментарію у розвідках, дали змогу актуалізувати європейський порівняльно-правовий дискурс на українських теренах, залучивши до наукового обігу зокрема концепції Е. Ренана, I. Тена, Е. Фрімена та інших мислителів. Водночас прихильність ученого, як і всієї Київської історикоюридичної школи, до історико-порівняльного методу згодом зазнала нищівної критики як «зброя буржуазної методології» у статті С.Г. Борисенка «Російське великодержавництво в концепції західноруського права» (1931 р.). Заразом порівняльний метод, який поєднувався з документалізмом («визнання тільки таких поглядів, які відповідають «точному змісту пам'яток») та описовістю, було визнано методологічно невірним. Цей висновок став початком стагнації історико-правового пізнання, наслідки чого відчутні й сьогодні.

Етапне значення у створенні цілісної картини історико-правового розвитку мали «Лекции по истории российского государственного права» М.О. Максимейка, які неодноразово були видані студентами Харківського університету (1902-1903 рр.) та врешті ним самим (1917 р.), що свідчило про популярність і збалансованість навчального курсу.

Окреме місце у творчій спадщині М.О. Максимейка посідають дослідження давньоруського права. Йому належала честь відкриття Московської редакції поширеної редакції Руської Правди (1888 р.). Він $є$ автором низки праць, серед яких «Мнимые архаизмы уголовного права Русской Правды» (1905 р.), «Опыт критического исследования Русской Правды. Краткая редакция» (1914 р.), «Речь по поводу Русской Правды перед диспутом в Университете св. Владимира 22 февраля 1915 г.» (1915 р.), «Система поширеної редакції Руської Правди» (1926 р.), «Про смердів Руської Правди» (1927 р.), «Закупы Русской Правды (1927 р.), «Інтерполяції в текстові поширеної Руської Правди» (1929р.). «До питання про класифікацію списків Руської Правди» (1936 р.), «Московская редакция Русской Правды» (1940р.), в яких викладена його власна версія «Руської Правди». Дискутуючи з визнаними фахівцями В.І. Сергеєвичем, М.Ф. Владимирським-Будановим, Л.К. Гетцем та багатьма іншими, він обстоював своє бачення змісту, системи як всієї пам'ятки, так і окремих ії норм.

Зокрема, оригінальним і переконливим є погляд М.О. Максимейка на Руську Правду як на втілення тогочасної правової доктрини, переконання про відчутний вплив римського права - головним чином законодавства Юстиніана - яке на той час було досить відоме поза межами Візантійської імперії. Науковець стверджував, що основою короткої редакції Руської Правди було давньоруське право, але система викладу була запозичена із римського права, до неї були включені не лише звичаї, а й князівські устави («Опыт критического исследования Русской Правды. Краткая редакция. Харьков» (1914 р.)). Учений доводив, що автор короткої редакції Руської Правди включив новгородське право не в повному обсязі, а доповнив його правом Київської землі, з урахуванням різноманітності звичаїв, які діяли на території Київської Русі.

Цікавою і дискусійною гіпотезою є гіпотеза про причини появи пам'ятки (приводом для складання Руської Правди була потреба відокремити давньоруське право від грецького (Номоканонів, які отримали 
назву Кормчих книг), адже широке розповсюдження Кормчої книги становило серйозну небезпеку для руського права, яка повинна була пробудити національну свідомість (тут, очевидно, він виказав себе прихильником теорії національного права М.Ф. Владимирського-Буданова).

Небезпідставним видається погляд на Руську Правду як на науковий твір у галузі юридичної літератури, а не збірник для керівництва судової практики («Опыт критического исследования Русской Правды» (1914 р.)) та про прямі впливи римського права на коротку редакцію Руської Правди тощо.

Цікавими є твердження про розмежування кримінальних та цивільних злочинів у Руській Правді, про виокремлення у пам'ятці державних злочинів, які мали специфічну особливість, оскільки переслідувались не судом, а в адміністративному порядку, про відповідальність територіальної общини не за незнаходження злочинців, а за відмову шукати («Мнимые архаизмы уголовного права Русской Правды». Вестник права. 1905. № 1-3).

«Академічний період» як узагальнюючий для українських студій професора Максимейка і як констатація визнання його високого фахового рівня, можна розпочати від 1905 р. М.О. Максимейко разом з іншими професорами Харківського університету (М.Ф. Сумцовим, Д.І. Багалієм, Т.І. Буткевичем та ін.), увійшов до складу Ради Харківського університету з питань про усунення тих обмежень, які з 1863 р. застосовуються до української мови і української літератури і які шкодять як Росії, так, особливо, і Україні у всіх формах їі морального життя, як підкреслювалось в ухваленому одноголосно 5 квітня 1905 р. рішенні ради ${ }^{17}$.

Подальшим етапом боротьби Максимейка за українську мову була діяльність, пов'язана 3 кодифікаційними потребами у НКЮ УСРР. Провадити систематизацію нормативно-правових актів він вважав за потрібне «у історичній послідовності, з відкиненням актів, прийнятих за виняткових умов (революції, громадянської війни); виключення із норм правової нерівності громадян; залучення населення до більшої державотворчої активності шляхом участі у правотворенні». Важливою складовою кодифікації він, як і інші відомі правники С. Веретка, С.С. Дністрянський, О.Л. Малицький та ін., вважав розвиток української юридичної термінології. Як фаховий дослідник пам'яток права, учений був свідомий того, наскільки важливим є адекватне термінологічне оформлення правових процесів і явищ. В умовах відсутності сучасної української правової термінології він наголошував на особливій ролі у кодифікаційних процесах перекладачів-упорядників, а часто в існуючих умовах авторам законодавчих актів. Він наголошував, що українське законодавство мало будуватися на сталій законодавчій базі та відповідали національним особливостям українського права та законодавства. Розроблені положення були викладені М.О. Максимейком у статті «Об украинской юридической терминологии» (Вестник советской юстиции. 1924. № 21) і підтримані Правничо-термінологічним відділом, що працював над правничою термінологією з 1919 р. при УАН (ВУАН), який «так саме й розумів своє завдання, що утворення сучасної правничої української термінології повинно базуватися на старовинній українській правничій термінології, яку він виучує не тим недоцільним способом, а читаючи самі акти від початку і до кінця, щоб, заглибившись в саму гущавину старовинного українського правничого життя, яке джерелом б'є зо всіх старовинних українських актів, правдиво зрозуміти і розшифрувати терміни, яких уживало українське право у оточенні повсякденних правничих казусів»18. Можна сказати, що певною мірою цей «план роботи» втілився у «Російсько-українському словнику правничої мови», виданого під редакцією А.Ю. Кримського (1926 р.) ${ }^{19}$.

Важливою складовою українознавчих студій ученого була його діяльність голови секції історії українського права при науково-дослідній кафедрі історії української культури Харківського інституту народної освіти. М.О. Максимейко, визначаючи загальний план роботи секції, наполягав, як видно 3 «Виписів 3 протоколів засідань Укрнауки про затвердження аспірантів», що секція «має поєднувати «вивчення соціального характеру правових норм українського історичного процесу та підготовку майбутніх викладачів 3 дисципліни «Ітсорії українського права». Також він пропонував літературу, з якою аспіранти мали ознайомитися насамперед, розподіляв теми доповідей та виступав перед аспірантами з власними науковими повідомленнями.

Його учнями були історики, майбутні професори Харківського університету С.М. Королівський та К.К. Шиян. Тут професор Максимейко вписав свою сторінку у шевченкознавство, долучившись до видання творів Кобзаря, яке готувалося у НДІ ім. Т. Шевченка. Він підготував коментарі деяких творів у вигляді розвідок «Про козацькі морські походи», «Про рабство в Криму та на Україні», «Про військову службу на Україні при Катерині II», «Становище міст на Україні в XVI-XVII», «Історія земельних відносин в Росії». На замовлення Київського інституту історії України ним також були підготовані розвідки-рецензії «Адміністрація та суд на Україні від XV до XVII ст.» та «Розбір частини підручника з історії України Гуслистого».

Аналізуючи науковий світогляд професора Максимейка, слід зазначити, що його інтелектуальна соціалізація відбувалася в ситуації, коли здійснювалось усталення фундаментальних основ класичної - і природничої, і гуманітарної наук, серед яких домінуючим було уявлення про еволюційний розвиток людства, його лінійність. Водночас спектр дослідницьких підходів, який пропонувався науковим середовищем, був доволі широким - від раціоналізму до емпіризму, від неокантіанства і позитивізму до матеріалізму і феноменології, чим науковець Максимейко тією чи іншою мірою послуговувався, залишаючись переважно на позитивістських позиціях.

Як представник школи західноруського права, учений поділяв іiі методологічну базу, яку в цілому можна визначити як історико-порівняльну з елементами соціологізму та еволюціонізму, що дає зокрема О.Ф. Скакун вважати, що «на противагу формально-юридичній юриспруденції, цю течію можна визначити як історичну школу права на Україні»20.

При цьому сам учений наголошував, що, говорячи про колективну ідею як джерело правотворення, він відмежовується як від німецької історичної школи права (з їі народним духом) та слов’янофілів («грунт, на 
якому вони стояли, слизький і ненауковий»), наголошуючи, що запозичує він її у тих позитивістів, які вчать про невідворотність і невблаганність спадкоємності («Сравнительное изучение истории права»). Це дає підстави І.Б. Усенку стверджувати: якщо класична історична школа права виросла з ідеалістичної німецької філософії, то українські історики права аналогічні ідеї виводили з філософського позитивізму 21.

Позитивістом він показує себе у аналізі сеймів Великого князівства Литовського, списків і норм Руської Правди тощо, зосереджуючись на аналізі норм (мотиви - це сфера політики, а не права). При цьому «навмисна юридизація» історичного дослідження серед іншого могла бути зумовлена становленням і утвердженням у той час історії права як юридичної науки поряд з «чистою історією» та пошуками власної методології та предмета.

Характерним для позитивізму М.О. Максимейка $є$ аналітичний метод дослідження: аналізуючи той чи інший об'єкт, він намагається отримати синтетичний умовивід - всебічно обгрунтовану інтерпретацію. Це в свою чергу зумовлює звертання до соціологічного та культурно-історичного контексту, ілюстрацією чого є, наприклад, бачення ученим походження Руської Правди, висвітлення процесу утворення обласних сеймів Великого князівства Литовського як передумови вального сейму тощо.

«Культурологічний ухил» у дослідженнях постулювала і його робота як голови секції історії українського права при науково-дослідній кафедрі історії української культури Харківського інституту народної освіти, метою діяльності якого було дослідження розвитку матеріальної й духовної культури українського народу, зокрема історії мистецтва, науки та літератури.

Загалом праці професора Максимейка є зразком витонченого наукового стилю, у яких відображені широка ерудиція, сумлінність, новаторство та сміливість у гіпотезах і висновках їх автора, які роблять їх цікавими для нових поколінь дослідників і забезпечують його хоча і відносно невеликій (близько 50 праць), але багатогранній науковій спадщині, активний науковий обіг.

1 Див., напр., Микола Олексійович Максимейко. Украӥнська радянська енцииллопедія. Київ: АН УРСР, 1962. Т. 8. С. 412 ; Максимейко Н.А. Украинская советская энииклопедия. Киев: Главная ред. укр. Советской энциклопедии, 1981. Т. 6. С. 248; Скакун О.Ф. Максимейко М.О. Радянська енциклопедія історії України. Київ: АН УРСР, 1971. Т. 3. С. 72; Максимейко Н.А. Славяноведение в дореволюиионной России: Библиографический словарь. Москва: Наука, 1979. С. 229; Скакун О.Ф. Максимейко Микола Олексійович. Юридична енциклопедія. Київ: «Українська енциклопедія» ім. М.П. Бажана. Т. 3. 2001. С. 557-558; Бондарук T.I. Максимейко Микола Олексійович. Антологія украӥнської юридичної думки: в 6 т. Київ: Вид. дім «Юридична книга», 2002. Т. 2. С. 278-279; Усенко І.Б. Максимейко Микола Олексійович (1870-1941). Академічна юридична думка. Київ: Ін Юре. 1998. С. 306; Скрипник П.І. Максимейко Микола Олексійович. Енциклопедія історії України: у т. / редкол.: В.А. Смолій (голова) та ін.; Інститут історії України НАН України. Київ: Наук. думка, 2009. Т. 6: Ла-Мі. С. 456.

2 Остапенко С.В. Науково-педагогічна та громадська діяльність М.О. Максимейка: дис. ... канд. іст. наук: 07.00.01. Харківський національний педагогічний ун-т ім. Г.С. Сковороди. Харків, 2008.

3 Державний архів м. Києва. Ф. 16. Оп. 465. Спр. 1423. Арк. 50-51.

4 Отчет о состоянии и деятельности Императорского Харьковского университета за 1914. Записки Императорского Харьковского Университета. 1915. № 1. Харьков: Тип. ун-та, 1915. С. 10, 38.

5 Міхневич Л. Витоки вищої жіночої освіти в Україні (кінець XIX - початок XX ст.). Юридична Україна. 2015. № 7-8. C. $78-85$.

${ }^{6}$ Кафедрі історії України Харківського національного університету імені В.Н. Каразіна 50 років. Харків: Вид-во ХНУ імені В.Н. Каразіна, 2007. С. 4.

7 Звідомлення III соціально-економічного відділу ВУАН за 1928 р. Вісті ВУАН. 1929. № 3-4. С. 57.

8 Богдашина О.М. Діяльність Харківської науково-дослідної кафедри історії української культури ім. акад. Д.І. Багалія (1921-1934рр.). Харків : Вид. ХДПУ, 1994. С. 95.

${ }^{9}$ Максимейко Н.А. Университетские известия. Киев: Тип. имп. унив. св. Владимира, 1894. № 7. № 9, № 10, № 12 .

10 Грибовский В. Рец.: Максимейко Н. Источники уголовных законов Литовского Статута. Журнал юридического общества при Императорском С.- Петербургском университете. 1895. Кн. 5. С. 9.

${ }_{11}$ К вопросу о Литовско-Русскихъ сеймах: (ответ проф. М. Любавскому). Санкт-Петербург: Сенат. тип., 1904. 21 с. Извлечено из Журн. М-ва Нар. Просвещения за 1904 г.

12 Максимейко Н.А. Русская Правда и Литовский Статут. Киев, 1904. С. 14.

13 Грушевський М. Рец.: Н.А. Максимейко «Русская Правда» и литовско-русское право (Сборник, посвященный М.Ф. Владимирскому-Буданову, С. 382-395). М.Н. Ясинский. Закупы «Русской Правды» и памятников западнорусского права. (ibid., С. 430-465). Т. 15. Серія «Рецензї та огляди» (1898-1904). Львів: Вид-во «Світ», 2012. С. $215-216$.

14 Бондарук Т. Західноруське право: дослідники і дослідження (Київська історико-юридична школа). Київ, 2000.

15 Максимейко М.О. Про досягнення в науці історії українського права за минуле десятиріччя. Червоне право. 1927. № 24. C. 1111 .

16 Інститут рукописів. Національна бібліотека України ім. В.І. Вернадського. Ф. 40. Спр. 494. Арк. 2.

17 Харківський національний університет ім. В.Н. Каразіна за 200 років. В.С. Бакіров, В.В. Кравченко, С.І. Посохов, В.В. Калініченко та ін. Харків: Фоліо, 2004. С. 255.

18 Максимейко М.О. До питання про українську правничу термінологію. Вестник советской юстиции. 1924 . № 24. C. $818-819$.

19 Усенко І.Б., Іванова А.Ю. Мовно-термінологічні проблеми в нормотворчій діяльності Української держави (гетьманату

П.П. Скоропадського). Часопис Київського університету права. 2005. № 1. С. 17-22.

20 Скакун О.Ф. Политическая и правовая мысль на Украине (1861-1917). Харьков, 1987. С. 142.

21 Усенко І.Б. Філософсько-правові основи наукових досліджень провідних правознавців Всеукраїнської Академії наук. Методологічні проблеми історико-правових досліджень: матеріали ХХІІІ Міжнародної історико-правової конференції 24-26 вересня 2010 р., м. Алушта / ред. колегія: І.Б. Усенко (голова), А.Ю. Іванова (відп. секр.), Л.П. Гарчева, Київ; Сімферополь: «ДОЛЯ», 2011. С. 67. 
Резюме ження).

Бондарук T.I. Видатний український правознавець Микола Олексійович Максимейко (до 150-річчя від дня народ-

У статті висвітлено основні етапи життєвого і творчого шляху відомого правознавця, історика права професора Максимейка. Приділено увагу науковому світогляду науковця, здійснено короткий аналіз здобутків «київського, харківського та академічного» періодів його творчості.

Ключові слова: правознавство, Микола Олексійович Максимейко, історія права, західноруське право, Руська Правда, порівняльне правознавство.

\section{Резюме}

Бондарук Т.И. Выдающийся украинский правовед Николай Алексеевич Максимейко (к 150-летию со дня рождения).

В статье отражены основные этапы жизненного и творческого пути известного правоведа, историка права профессора Максимейко. Уделено внимание научному мировоззрению ученого, осуществлен краткий анализ достижений «киевского, харьковского и академичного» периодов его творчества.

Ключевые слова: правоведение, Николай Алексеевич Максимейко, история права, западнорусское право, Русская Правда, сравнительное правоведение.

\section{Summary}

Tetyana Bondaruk. Prominent Ukrainian jurist Mykola Oleksiiovych Maksymeiko (to the 150th anniversary of his birth).

The article provides an overview and description of the life and career of the prominent Ukrainian jurist professor M.O. Maksymeyko, an attempt is made to highlight the key issues of his creative heritage in the context of the development of historical and legal science. On the basis of the analysis of multifaceted scientific-teaching, public, educational activity of M.O. Maksymeyko the Kyiv, Kharkiv and academic periods are singled out and analyzed.

Thus, the first «Kyiv period» of the scholar is a period of study of Lithuanian-Russian or Western Russian law, on the basis of which he argued his own position on the law of Western, and actually Ukrainian, clearly distinguishing the law of North-Eastern Russia (1). Moscow Sudebniki, in the Code of 1649; the law of Lithuanian Russia, the best embodiment of which is the Lithuanian Statute (2); the law of the North-Western region, codified in the Deeds of Novgorod and Pskov (3). He defined the historical development of Ukrainian law as: Ukrainian law - the law of Cossack Ukraine, which through the Lithuanian Statute is associated with the Russian Pravda.

The «Kharkiv Period» is a period of establishing a research methodology, including a declaration of commitment to the comparative law method, a generalization of the course of historical and legal development, and the creation of a series of works devoted to Russkaya Pravda. «Comparative Study of the History of Law» (1898) became a bestseller and put it together with M.M. Kovalevsky, F.V. Taranovsky in the forefront of comparative jurists. M.O. Maksimeyko's «Lectures on the History of Russian State Law» were of stage importance in creating a holistic picture of historical and legal development. A special place in the creative heritage.

M.O. Maksimeyko occupy the study of ancient $\mathrm{n}$ law. In the series of works of the scientist about the Russian Truth original author's hypotheses about its system, sources, authorship, etc. are expressed and proved. The «academic period» is a generalization for Professor Maksymeyko's Ukrainian studies. Among them are works on substantiation of the role and place of the Ukrainian language in the rule of law, ways of its codification and attention to the cultural and historical context in the study of law. Professor Maksymeyko's scientific worldview is defined as positivist, the methodological basis of his studies was the historical-comparative method with elements of sociology and evolutionism, which gives in particular grounds for its belonging to a modified historical school of law. It is stated that the multifaceted scientific heritage of Maksymeyko is in active scientific circulation, which is due to the high scientific level of his research.

Key words: jurisprudence, Mykola Oleksiyovych Maksymeiko, history of law, Western Russian law, Ruska Pravda, comparative jurisprudence. 